\title{
The Neoperozoic Fangcheng Nb-rich alkaline rocks, central China: magma origin and evolution
}

\author{
YU-XIANG ZHU ${ }^{1}$, LIAN-XUN WANG ${ }^{1}$, CHANG-QIAN \\ MA $^{1}$, MICHAEL WIEDENBECK ${ }^{2}$ \\ ${ }^{1}$ School of Earth Sciences, China University of Geosciences, \\ 430074, Wuhan, China \\ ${ }^{2}$ GFZ German Research Centre for Geosciences, 14473 \\ Potsdam, Germany \\ (*correspondence: lianxunwang@cug.edu.cn)
}

The Fangcheng alkaline complex is located at the northeastern margin of North Qinling orogen in central China. It consists of nepheline syenite, biotite syenite, alkali-feldspar syenite, quartz syenite and syenogranite. Notably, all alkaline rocks are enriched in $\mathrm{Nb}$, and this is particular true for the nepheline syenites $(\mathrm{Nb}=161-461 \mathrm{ppm})$.

Titanite and zircon $\mathrm{U}-\mathrm{Pb}$ dating reveal that these rocks simultaneously emplaced between 867 and $833 \mathrm{Ma}$. They are strongly enriched in ferroan, HFSEs ( $\mathrm{Nb}, \mathrm{Zr}$, Th) and REEs, wirh an obvious depletion of $\mathrm{Ba}, \mathrm{Sr}$ and $\mathrm{Eu}$. The nepheline syenites and biotite syenites display relatively higher $\varepsilon \mathrm{Nd}(\mathrm{t})$ values $(-0.7$ to -1.5$)$ and initial ${ }^{208} \mathrm{~Pb} /{ }^{204} \mathrm{~Pb}$ ratios (36.12-37.61) than the quartz syenites and syenogranites (4.5 to -4.9 and $23.40-36.72$, respectively). Likewise, lower zircon $\varepsilon \mathrm{Hf}(\mathrm{t})$ values $(-4.2$ to -6.9$)$ were recorded by the quartz syenites and syenogranites.

Based on an integration of our results, we propose that the Fangcheng alkaline rocks were generated by partial melting of an enriched mantle during which a fractionation of an alkali basaltic melt directly produced the nepheline syenites. Segregation of sodic minerals caused the residual melts to evolve towards a potassium-rich composition of the biotite syenites and alkali-feldspar syenites. The quartz syenites and syenogranites are the end products of a highly evolved melt containing a significant degree of contamination by crustal materials. Enrichment of $\mathrm{Nb}$ in all lithologies is controlled by both magmatic and hydrothermal processes. In an initial Fand HFSE-rich magmatic system, fractionation of $\mathrm{Nb}$-poor mineral phases led to a concentration of both $\mathrm{F}$ and $\mathrm{Nb}$ in the residual melts, as is recorded by Nb-rich titanite. Supsequent hydrothermal metasomatism by Na- and F-rich fluids induced further remobilization and precipitation of $\mathrm{Nb}$ to form secondary titanite, pyrochlore, euxenite and $\mathrm{Nb}$-bearing rutile. The Fangcheng complex was generated in a post-collisional extensional regime, implying that the assembly of the Rodinia supercontinent had been completed prior to ca. $830 \mathrm{Ma}$. 